\title{
Penerapan model pembelajaran think pair share untuk meningkatkan kemampuan pemecahan masalah barisan dan deret pada siswa SMKN 5 Malang
}

\author{
Andrie Kurniawan M., Askury* \\ Universitas Negeri Malang, Jl. Semarang No. 5 Malang, Jawa Timur, Indonesia \\ *Penulis korespondensi, Surel: askury.fmipa@um.ac.id
}

Paper received: 01-10-2021; revised: 15-10-2021; accepted: 31-10-2021

\begin{abstract}
Nowadays, the students are required to build understanding in problems solving independently. It is intended so that students can understand and are able to complete the concepts with their own ideas. Think Pair Share model in Cooperative Learning is one type of cooperative learning model, blending of self-learning and learning in groups. Think Pair Share model in Cooperative Learning can assist students in interpreting their ideas together and improve understanding.

This study used a qualitative approach and designed using class action research. This study aims to determine the improvement of students' mathematical problem solving skills through Think Pair Share model in cooperative learning. Subjects in this study were students of grade X CEC 1 SMKN 5 Malang, academic year 2013/2014, amounting to 28 students. There are some stages in this research: (1) planning, (2) action, (3) observation, (4) reflection in each cycle. The data collection is about the implementation of cooperative learning model Think Pair Share and mathematical problem-solving ability of students that are measured from every test at the end of cycle using a scoring rubric mathematical problem solving ability. It is also supported by other instruments, such as interviews, documentation, field notes.

The results of this study indicate that 1) the application of Think Pair Share learning model has been implemented in two cycles with the first two stages of the cycle and the second cycle with one stage, and 2) the application of Think Pair Share model in cooperative learning is improving mathematical problem solving ability. The increasing was shown from the increasing in the implementation of cooperative learning Think Pair Share that is 81.135 percent in the first cycle increased to 84.86 percent in the second cycle. Mathematical problem-solving ability of students increase at an average of 50.23 percent in the first cycle into 60.12 percent in the second cycle.
\end{abstract}

Keyword :

Abstrak
Saat ini siswa dituntut untuk mampu membangun pemahaman dalam penyelesaian masalah secara
mandiri. Hal ini bertujuan agar siswa dapat memahami konsep dan mampu menyelesaikan dengan
ide-ide mereka sendiri. Model pembelajaran kooperatif tipe Think Pair Share merupakan salah satu
tipe model pembelajaran kooperatif perpaduan dari belajar mandiri dan belajar secara
berkelompok. Model pembelajaran kooperatif tipe Think Pair Share dapat membantu siswa dalam
menginterpretasikan ide-ide mereka bersama dan memperbaiki pemahaman.

Penelitian ini menggunakan pendekatan kualitatif dan dirancang dengan menggunakan penelitian tindakan kelas. Penelitian ini bertujuan untuk mengetahui peningkatan kemampuan pemecahan masalah matematika siswa melalui model pembelajaran kooperatif tipe Think Pair Share. Subjek dalam penelitian ini adalah siswa kelas X KTK 1 SMKN 5 Malang tahun ajaran 2013/2014 yang berjumlah 28 siswa. Tahap dalam penelitian ini adalah: (1) perencanaan; (2) tindakan; (3) observasi; (4) refleksi di setiap siklusnya. Data yang dikumpulkan adalah pelaksanaan model pembelajaran kooperatif tipe Think Pair Share dan kemampuan pemecahan masalah matematika siswa yang diukur dari tes setiap akhir siklus dengan menggunakan rubrik penskoran kemampuan pemecahan masalah matematika. Selain itu juga didukung dengan instrument lain seperti wawancara, dokumentasi, catatan lapangan. 
Hasil penelitian ini menunjukkan bahwa 1) penerapan model pembelajaran Think Pair Share telah dilaksanakan dengan dua siklus dengan siklus pertama dua tahapan dan siklus kedua dengan satu tahapan, dan 2) penerapan model pembelajaran kooperatif tipe Think Pair Share meningkatkan kemampuan pemecahan masalah matematika. Peningkatan tersebut ditunjukkan dari peningkatan pelaksanaan pembelajaran kooperatif tipe Think Pair Share yakni 81,135 persen pada siklus I meningkat menjadi 84,86 persen pada siklus II. Kemampuan pemecahan masalah matematika ratarata siswa meningkat dari 50,23 persen pada siklus I menjadi 60,12 persen pada siklus II.

Kata kunci: pembelajaran kooperatif tipe Think Pair Share; kemampuan pemecahan masalah matematika

\section{Pendahuluan}

Berdasarkan hasil observasi yang dilakukan peneliti pada tanggal 7-12 Oktober 2013 di SMK N 5 Malang masih banyak ditemukan siswa yang mengalami hambatan dan kendalakendala dalam menyelesaikan soal, atau dikatakan siswa mengalami kesulitan dalam menyelesaikan soal-soal. Hal ini disebabkan karakteristik matematika, yaitu objeknya yang abstrak, konsep dan prinsipnya berjenjang, dan prosedur pengerjaannya banyak memanipulasi bentuk-bentuk ternyata menimbulkan kesulitan dalam belajar matematika karena mereka beranggapan sebagai siswa SMK hanya perlu keterampilan. Dari hasil tes pada materi sebelumnya, diketahui nilai rata-rata siswa kelas X KTK I adalah 45,9. Siswa cenderung malas apabila menemukan soal yang terlalu panjang, misalkan siswa memperoleh soal berbentuk cerita. Selain itu, siswa juga kurang aktif dalam pembelajaran matematika. Mereka cenderung menerima apa yang disampaikan guru, sehingga dalam pengerjaan soal yang berbeda dengan contoh yang disampaikan guru maka siswa akan mengalami hambatan. Selain itu kurikulum 2013 yang saat ini diterapkan, kegiatan belajar sudah tidak berpusat pada guru namun saat ini lebih berpusat pada siswa dengan kegiatan kelompok. Dari hasil observasi yang telah dilakukan peneliti, siswa dalam kelompok besar cenderung kurang efektif, dikarenakan banyak siswa yang kurang bertanggung jawab pada kelompoknya. Selain itu, kecenderungan siswa yang tingkat kemampuan tinggi dan rendah memunculkan sikap arogan pada siswa kemampuan tinggi dan sikap malas atau menerima saja pada siswa kemampuan rendah akibat tidak munculnya diskusi dalam kelompok. Hal ini menimbulkan kendala antara lain, rendahnya kemampuan siswa dalam menganalisis masalah, rendahnya kemampuan siswa dalam merancang penyelesaian masalah, dan rendahnya kemampuan dalam perhitungan.

Salah satu metode yang dapat mengatasi masalah yang dihadapi siswa di atas adalah metode Think-Pair-Share. Metode Think-Pair-Share merupakan metode pembelajaran kooperatif yang sederhana. Dalam pembelajaran Think-Pair-Share (TPS), siswa mampu mengembangkan pemahaman konsep secara mandiri dan dapat bertukar pikiran dengan siswa lain. Dalam kemampuan pemecahan masalah, pemahan merupakan salah satu kriteria proses dari pemecahan masalah. Dengan menggunakan metode Think-Pair-Share (TPS) diharapkan pula mengatasi keadaan siswa yang enggan bertanya terhadap ketidakmengertian tentang konsep kepada guru, namun dengan tanpa malu-malu mereka dapat bertanya kepada temannya. Selain itu, kelompok kecil akan lebih efektif karena muncul tanggung jawab yang besar dari anggota kelompoknya yang menyadari jumlah anggota kelompok yang sedikit. Seperti yang diungkapkan Slavin dalam Suprayekti (2006) teknik pembelajaran kooperatif adalah berbagai metode pembelajaran yang memungkinkan para siswa bekerja di dalam kelompok kecil saling membantu satu sama lain dalam mempelajari materi tertentu. Beberapa penelitian diantara yaitu oleh Utama tahun 2012 tentang "Penerapan Model Pembelajaran Kooperatif tipe Think Pair Share untuk Memahamkan Materi 
Logaritma Kelas SMK" diperoleh bahwa pembelajaran dengan TPS dapat meningkatkan hasil belajar siswa yaitu dari $17,9 \%$ pada siklus I meningkat menjadi $46,4 \%$ pada siklus II, penelitian oleh Ivalia tahun 2009 tentang "Penerapan Pembelajaran Think Pair Share (TPS) untuk Meningkatkan Hasil Belajar Matematika Siswa pada Materi Segitiga di Kelas VII-C SMP Negeri 2 Besuk Tahun Ajaran 2009/2010" diperoleh peningkatan hasil belajar dari 58,33\% menjadi $75 \%$ pada siklus I dan $86 \%$ pada siklus II.

Materi barisan dan deret pada kurikulum 2013 disajikan pada kelas X. Sesuai dengan silabus pada kurikulum 2013, peneliti memilih materi barisan dan deret. Pada materi ini banyak siswa yang hanya sekedar menghafal rumus saja dan kurangnya pemahaman. Siswa hanya sekedar menenrima rumus akhirnya saja. Hudojo (2005) menyatakan inti dari pembelajaran matematika adalah pemahaman bukan perolehan. Selama ini, penyampaian materi barisan dan deret bersifat monoton yaitu menyajikan materi, memberi contoh soal, dan memberi soal latihan. Sehingga aktivas siswa cenderung rendah dan siswa menghafal rumus sehingga sulit menyelesaikan masalah yang bersifat aplikatif.

Dari uraian yang telah dijelaskan, penulis akan meneliti penerapan model pembelajaran Think-Pair-Share (TPS) untuk membantu mengatasi masalah yang telah dijelaskan sebelumnya. Terkait dengan hal tersebut, penulisan hasil penelitian ini berjudul " Penerapan Model Pembelajaran Think Pair Share untuk Meningkatkan Kemampuan Pemecahan Masalah Barisan dan Deret pada Siswa SMKN 5 Malang".

\section{Metode}

Penelitian ini termasuk penelitian kualitatif. Dalam penelitian ini dilakukan pendekatan kualitatif karena dalam melakukan tindakan, tindakan terhadap subjek penelitian sangat diutamakan. Penelitian yang akan dilakukan termasuk dalam Penelitian Tindakan Kelas (PTK). Subyek dalam penelitian ini yaitu siswa SMK N 5 Malang kelas X KTK I tahun ajaran 2013/2014.

Instrumen yang digunakan dalam penelitian ini adalah lembar kegiatan siswa, tes, lembar observasi, catatan lapangan, observasi dan dokumentasi. Dengan teknik pengumpulan datanya ada yang dilakukan selama pembelajaran, atau diluar pembelajaran.

Sumber data dalam penelitian ini ada 2 jenis data, yaitu data kualitatif dan data kuantitatif. Data kualitatif berupa catatan lapangan dan lembar observasi, selain itu data kualitatif didukung dari dokumentasi, penjelasan hasil pengerjaan latihan soal, LKS dan tes akhir siklus. Data kuantitatif diperoleh dari nilai tes akhir.

Analisis data dimulai dengan menelaah seluruh data yang tersedia. Teknik analisis data didasarkan pada jenis data. Untuk data kualitatif, analisis data yang dilakukan, yaitu mereduksi data, menyajikan data dan menarik kesimpulan. Mereduksi data adalah kegiatan menyeleksi, memfokuskan dan menyederhanakan semua data yang telah diperoleh untuk penyusunan laporan penelitian. Menyajikan data yaitu mongorganisasikan data hasil reduksi dalam bentuk naratif. Menarik kesimpulan adalah memberikan kesimpulan terhadap penafsiran, evaluasi dan tindakan. Untuk data kuantitatif analisis yang digunakan dalam penelitian ini adalah analisis validitas instrumen dan analisis kemampuan pemecahan masalah. Analisis validitas instrumen digunakan untuk mengetahui kevalidan instrumen yang digunakan dalam penelitian. Kevalidan instrumen dihitung dengan rumus 
$\%$ Kevalidan Instrumen $=\frac{\sum \text { skor }}{\text { skor maksimal }} \mathbf{x 1 0 0} \%$

dengan kriteria seperti tabel 1 sebagai berikut :

Tabel 1 Kriteria Penskoran Instrumen Penelitian

\begin{tabular}{ll}
\hline Persentase skor yang diperoleh (\%) & Nilai \\
\hline $85-100$ & Sangat valid \\
$65-84$ & Valid \\
$55-64$ & Kurang valid \\
$0-54$ & Tidak valid \\
\hline
\end{tabular}

Teknik analisis data pada kemampuan pemecahan masalah matematika siswa akan dilakukan sebagai berikut, memberi penilaian terhadap indikator pembelajaran sesuai dengan kriteria yang telah ditentukan sebagai berikut,

Tabel 2 Skor Kemampuan Pemecahan Masalah Masalah

\begin{tabular}{|c|c|c|c|c|}
\hline Kriteria & 4 & 3 & 2 & 1 \\
\hline $\begin{array}{l}\text { Memahami } \\
\text { masalah }\end{array}$ & $\begin{array}{l}\text { Menidentifikas } \\
\text { i faktor khusus } \\
\text { yang } \\
\text { mempengaruhi } \\
\text { pendekatan }\end{array}$ & $\begin{array}{l}\text { Memahami } \\
\text { masalah }\end{array}$ & $\begin{array}{l}\text { Cukup } \\
\text { memahami } \\
\text { masalah untu } \\
\text { menyelesaian } \\
\text { sebagian } \\
\text { masalah atau } \\
\text { memperoleh } \\
\text { sebagian solusi }\end{array}$ & $\begin{array}{l}\text { Tidak } \\
\text { memahami } \\
\text { masalah untuk } \\
\text { memulai atau } \\
\text { membuat } \\
\text { peningkatan }\end{array}$ \\
\hline $\begin{array}{l}\text { Menggunakan } \\
\text { informasi secara } \\
\text { tepat }\end{array}$ & $\begin{array}{l}\text { Menjelaskan } \\
\text { mengapa } \\
\text { informasi } \\
\text { tertentu adalah } \\
\text { hal-hal yang } \\
\text { perlu untuk } \\
\text { penyelesaian }\end{array}$ & $\begin{array}{l}\text { Menggunakan } \\
\text { seluruh } \\
\text { informasi yang } \\
\text { tepat secara } \\
\text { benar }\end{array}$ & $\begin{array}{l}\text { Menggunakan } \\
\text { beberapa } \\
\text { informasi yang } \\
\text { tepat secara } \\
\text { benar }\end{array}$ & $\begin{array}{l}\text { Penggunakan } \\
\text { informasi yang } \\
\text { tidak tepat }\end{array}$ \\
\hline $\begin{array}{l}\text { Mengaplikasika } \\
\text { n prosedur yang } \\
\text { tepat }\end{array}$ & $\begin{array}{l}\text { Menjelaskan } \\
\text { mengapa } \\
\text { prosedur tepat } \\
\text { untuk masalah } \\
\text { tersebut }\end{array}$ & $\begin{array}{l}\text { Mengaplikasika } \\
\text { n prosedur yang } \\
\text { tepat secara } \\
\text { lengkap }\end{array}$ & $\begin{array}{l}\text { Mengaplikasika } \\
\mathrm{n} \text { beberapa } \\
\text { prosedur yang } \\
\text { tepat }\end{array}$ & $\begin{array}{l}\text { Mengaplikasika } \\
\text { n prosedur yang } \\
\text { tidak tepat }\end{array}$ \\
\hline $\begin{array}{l}\text { Menggunakan } \\
\text { penggambaran } \\
\text { atau } \\
\text { representasi }\end{array}$ & $\begin{array}{l}\text { Menggunakan } \\
\text { gambaran yang } \\
\text { tidak biasa } \\
\text { dalam } \\
\text { ketelitian } \\
\text { matematika }\end{array}$ & $\begin{array}{l}\text { Menggunakan } \\
\text { suatu } \\
\text { representasi } \\
\text { atau gambaran } \\
\text { masalah yang } \\
\text { jelas }\end{array}$ & $\begin{array}{l}\text { Menggunakan } \\
\text { suatu } \\
\text { representasi } \\
\text { yang } \\
\text { memberikan } \\
\text { beberpa } \\
\text { informasi } \\
\text { penting tentang } \\
\text { masalah }\end{array}$ & $\begin{array}{l}\text { Menggunakan } \\
\text { suatu } \\
\text { representasi } \\
\text { yang } \\
\text { memberkan } \\
\text { sedikit atau } \\
\text { informasi yang } \\
\text { tidak signifikasn } \\
\text { tentang } \\
\text { permasalahan }\end{array}$ \\
\hline $\begin{array}{l}\text { Menjawab } \\
\text { masalah }\end{array}$ & $\begin{array}{l}\text { Solusi } \\
\text { permasalahan } \\
\text { yang benar dan }\end{array}$ & $\begin{array}{l}\text { Solusi yang } \\
\text { benar }\end{array}$ & $\begin{array}{l}\text { Kesalahan } \\
\text { menyalin, } \\
\text { kesalahan }\end{array}$ & $\begin{array}{l}\text { Tidak menjawab } \\
\text { atau jawaban } \\
\text { salah berdasar }\end{array}$ \\
\hline
\end{tabular}




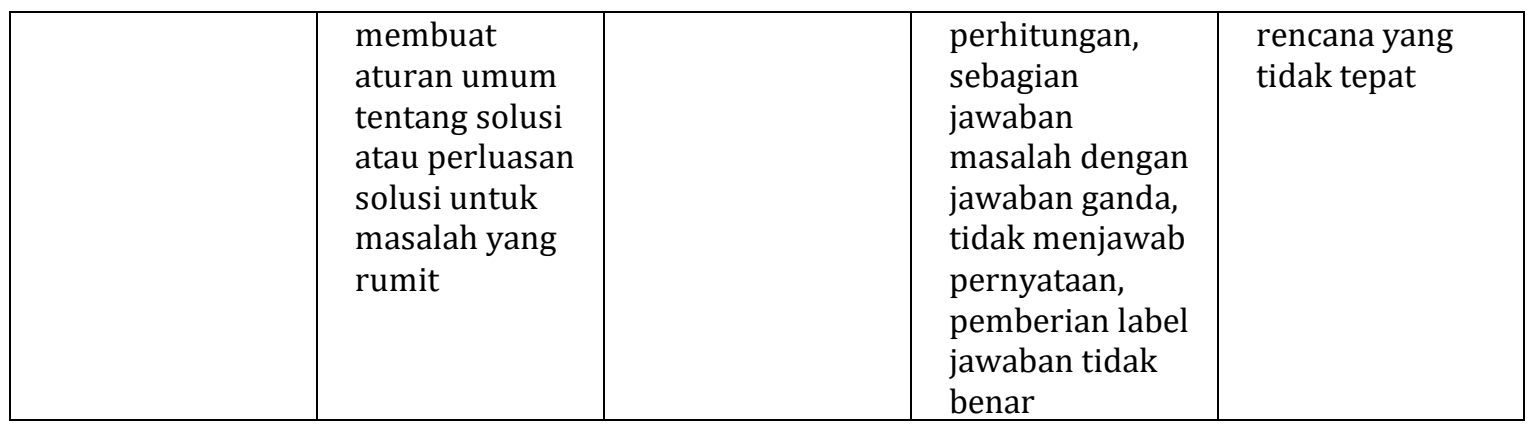

Mengolah skor yang didapat dari hasil tes untuk mengetahui data tentang kemampuan pemecahan masalah masalah siswa maka hasil tes yang berupa skor diolah dengan rumus berikut

$$
\text { Tingkat Penguasaan }=\frac{\text { jumlah skor yang diperoleh }}{\text { jumlah skor maksimal }} \times 100 \%
$$

Kriteria penggolongan kemampuan pemecahan masalah siswa adalah sebagai berikut

Tabel 3 Tingkat Penguasaan Kemampuan Pemecahan Masalah

\begin{tabular}{ll}
\hline Tingkat Penguasaan & Kriteria \\
\hline $85 \%-100 \%$ & Sangat Baik \\
$70 \%-84 \%$ & Baik \\
$55 \%-69 \%$ & Cukup Baik \\
$40 \%-54 \%$ & Kurang Baik \\
$0 \%-39 \%$ & Sangat Kurang \\
\hline
\end{tabular}

Pengecekan keabsahan data dalam penelitian ini menggunakan kriteria derajat kepercayaan dan teknik pemeriksaan ketekunan pengamatan dan triangulasi sesuai yang dipaparkan Moleong (2010:330) yaitu ketekunan pengamatan dan triangulasi. Triangulasi yang dilakukan dalam penelitian ini adalah triangulasi dengan metode, yang terdapat dua strategi yaitu (1) membandingkan dan mengecek kembali derajat kepercayaan penemuan hasil penelitian yang diperoleh melalui teknik pengumpulan data yang berbeda, (2) pengecekan derajat kepercayaan beberapa sumber data dengan metode yang berbeda.

\section{Hasil dan Pembahasan}

Kemampuan pemecahan masalah matematika siswa pada penelitian ini diperoleh dari skor tes siklus pertama dan skor tes siklus kedua. Presentase pencapaian kemampuan pemecahan masalah matematika siswa dapat dilihat pada tabel 5.1 berikut.

Tabel 4 Peningkatan Kemampuan Pemecahan Masalah Matematika Siswa Siklus I dan Siklus II

\begin{tabular}{l|l|l}
\hline Tindakan & $\begin{array}{l}\text { Prosentase kemampuan } \\
\text { pemecahan masalah matematika } \\
\text { siswa }\end{array}$ & $\begin{array}{l}\text { Kriteria kemampuan } \\
\text { pemecahan masalah } \\
\text { matematika siswa }\end{array}$ \\
\hline Siklus I & $50,23 \%$ & $\begin{array}{l}\text { Kurang Baik } \\
\text { Cukup Baik }\end{array}$ \\
Siklus II & $60,12 \%$ & \\
\hline
\end{tabular}


Peningkatan kemampuan pemecahan masalah matematika siswa dari siklus I ke siklus II dapat disajikan dalam diagram garis berikut.

Gambar 1 Grafik Peningkatan Kemampuan Pemecahan Masalah Matematika Siswa

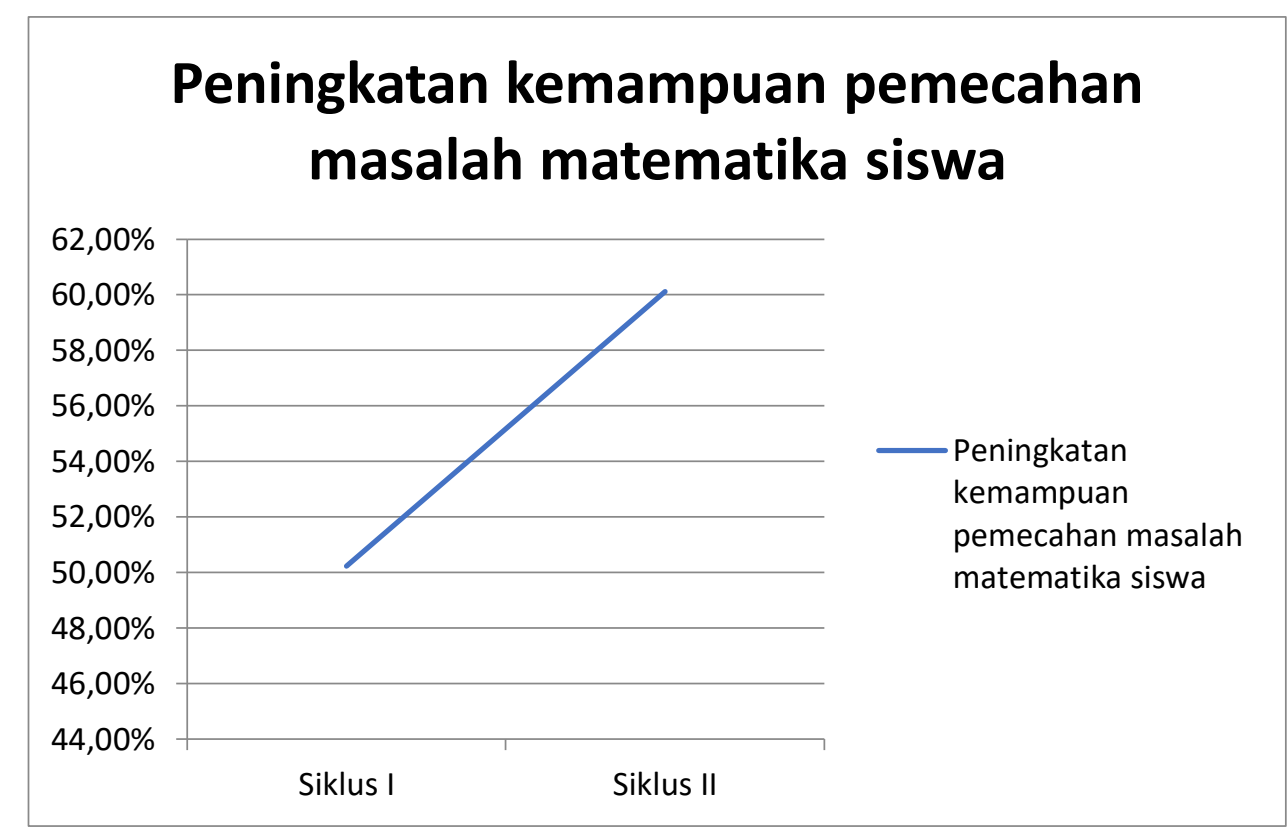

Pada siklus I kemampuan pemecahan masalah matematika siswa adalah sebesar $50,23 \%$ dengan kriteria kurang baik. Hal ini disebabkan siswa belum terbiasa dengan pembelajaran yang diterapkan dan belum terbiasa menyelesaikan permasalah yang kontekstual dan berbentuk uraian. Selain itu mereka belum mampu menuliskan penyelesaian secara sistematis sesuai dengan kriteria kemampuan pemecahan masalah.

Dengan menerapkan pembelajaran Think Pair Share kemampuan pemecahan masalah dapat meningkat, hal ini ditunjukkan kemampuan pemecahan masalah pada siklus II meningkat sebesar 9,89\% menjadi $60,12 \%$.

Tahap pendahuluan guru menjelaskan materi secara garis besar kepada siswa berdasarkan kompetensi yang harus dicapai dimana siswa memperhatikan penjelasan guru dengan baik.

Tahap berfikir (think) pada tahap ini guru membagikan LKS yang harus dikerjakan oleh siswa secara berpasangan. Tahap berpasangan (pair) guru meminta siswa untuk dua kelompok untuk bergabung, kemudian guru meminta siswa untuk berdiskusi, siswa mendiskusikan hasil jawaban dari LKS yang telah dikerjakan sebelumnya.

Tahap berbagi (share) pada tahap ini guru meminta siswa untuk mem- presentasikan hasil diskusi secara berkelompok di depan kelas, guru memilih kelompok secara acak atau meminta secara suka rela kelompok yang ingin maju. Untuk kelompok lain yang tidak presentasi, mereka diminta untuk memperhatikan dan memberikan tanggapan atas apa yang dipresentasikan oleh kelompok yang bertugas untuk presentasi. 
Siklus II, kemampuan pemecahan masalah matematika adalah cukup baik. Secara keseluruhan terjadi peningkatan, namun masih ada siswa yang mengalami penurunan kemampuan pemecahan masalahnya.

\section{Simpulan}

Penerapan model pembelajaran kooperatif tipe Think Pair Share mampu meningkatkan kemampuan pemecahan masalah matematika siswa kelas X KTK 1 SMK N 5 Malang, dengan melihat terjadinya peningkatan kemampuan pemecahan masalah matematika pada siklus I sebesar 50,23\% dan siklus II meningkat $60,12 \%$. Karena dalam pembelajaran TPS (Think Pair Share) siswa diberi kesempatan untuk memikirkan solusi dari masalah yang dihadapi. Kemudian diberikan kesempatan untuk berdiskusi untuk saling bertukar pendapat menentukan solusi masalah yang dihadapi dengan tepat. Selanjutnya, siswa diberi kesempatan untuk menyampaikan hasil diskusi mereka kedepan kelas sebagai bentuk penguatan dari hasil diskusi yang telah dilakukan. Dalam diskusi ini, siswa saling mengutarakan pendapat untuk menemukan solusi yang tepat dari masalah yang dihadapi.

\section{Daftar Rujukan}

\section{Anonim. $\quad(2012$} http://www.psychologymania.com/2012/12/kemampuan-pemecahan-masalah-matematika.html

Anonim. (2012, Maret 29). Model pembelajaran kooperatif tipe think-pair-share http://www.tuanguru.com/2012/06/model-pembelajaran-think-pair-share.html

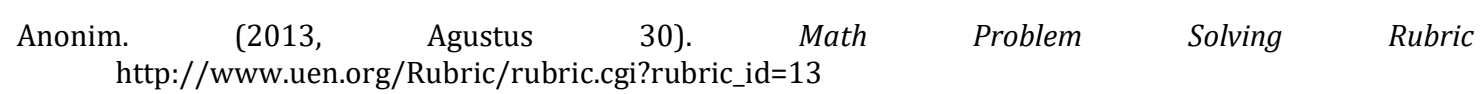

Ardiansyah, Ansori M. (2011). Pengertian pembelajaran kooperatif http://www.majalahpendidikan.com/2011/04/pengertian-pembelajaran-kooperatif.html

Arikunto, S. (2006). Prosedur penelitian suatu pendekatan praktik edisi VI. Jakarta: PT Rineka Cipta.

Arikunto, S., Suhardjono \& Supardi. (2009). Penelitian tindakan kelas. Jakarta: PT Bumi Aksara.

Arikunto, Suharsimi. (1992). Penelitian tindakan kelas. Jakarta: Bumi Aksara.

Icha, Nisa. (2011). Pengertian pembelajaran matematika http://veynisaicha.blogspot.com/2011/07/pengertian-pembelajaran-matematika.html

Holil, Anwar. (2007). Model pembelajaran koopatif http://anwarholil.blogspot.com/2007_09_01_archive.html

Hudojo, Herman. (2005). Pengembangan kurikulum dan pembelajaran matematika. Malang : Penerbit Universitas Negeri Malang.

Japa, I Gusta Ngurah. (2008). Peningkatan kemampuan pemecahan masalah matematika terbuka melalui investigasi bagi siswa kelas V SD 4 Kaliuntu 60-73. JPPP, Lembaga Penelitian Undiksha

Moleong, L.J. (2010). Metodologi penelitian kualitatif. Bandung: PT Remaja Rosdakarya.

NCTM. (2000). Principles and standards for school mathematics. Reston, Virginia: The National Council of Teachers of mathematics, Inc.

Riyanti. (2012, Maret 30). Kemampuan pemecahan masalah matematis. http://sinriyanti.blogspot.com/2012/10/kemampuan-pemecahan-masalah-matematis.html

Setiawan. (2011, Maret 29). Standar proses pembelajaran matematika http://setiawanpendidikanmatematika.blogspot.com/2011/04/ standar-proses-pembelajaran-matematika.html

Sriyanto. (2010, Maret 29). Pengertian pembelajaran kooperatif http://ian43.wordpress.com/2010/12/23/pengertian-pembelajaran-kooperatif/

Suherman, Erman. (2001). Strategi pembelajaran matematika kontemporer. Bandung: UPI.

Sujono. (1988). Pengajaran matematika untuk sekolah menengah. Jakarta : Departemen Pendidikan dan Kebudayaan Direktorat Jendral Pendidikan Tinggi. 